\title{
Assessment of Air Biofiltration Adequacy in Africa and the Caribbean
}

\author{
J. Perez, M. Reiser, K. Fischer \\ Department of Solid Waste Management and Emissions \\ Institute for Sanitary Engineering, Water Quality and Solid Waste Management, ISWA \\ Stuttgart, Germany
}

\begin{abstract}
Odors and volatile organic compounds (VOCs) are typical products of industrial processes that may cause nuisances and potential environmental threats. Biofiltration is a mature technology that employs a biofilm and a water layer to eliminate odorous and pollutants in the exhaust gases. The purpose of this research was to assess the feasibility of biofiltration to be established in Africa and the Caribbean. After an exhaustive literature review and the utilization of an online survey, several outputs regarding its potential to be implemented in these regions were found. Results indicate that South Africa and Nigeria represent the most feasible countries for a prompt establishment of the technology in Africa. In the case of the Caribbean countries, in the Dominican Rep., Jamaica and Trinidad and Tobago emission targets for some VOCs in particular industrial sectors were found. However, in the case of Cuba this information was very restricted. The preliminary survey indicated that people recognize there are problems with odors, though, biofiltration was practically unknown by the participants. The results of this research indicate that Biofiltration is an emission control technology that has considerable applicability in both regions and its introduction will benefit remarkably several productive sectors in order to enable them to comply with regulations, and towards further implementation of sustainable technologies.
\end{abstract}

\section{Introduction}

As population enlarges, increases the competence for land uses and possible problems may arise due to the nuiasances that the proximity to odor/pollutant emitting sources with households may generate. In order to protect the environment and assure a certain air quality, governments have established legislative regulating structures, by assigning institutions and designating standards to limit the generation of polluting substances and the emission of air pollutants [1].
VOCs may be originated from chemical mechanisms, solvent use, petroleum processing and other sources [2], [3]. While odors are generated from livestock, food processing industries, landfills, waste water treatment plants, among others [4]. Odors may not cause serious diseases, however, their persistence causes nuiasances to sensitive people [5]; and concerning VOCs, they may be precursors of pollutants that degrade the ozone layer [6]; thus waste gases are to be treated.

The purpose of this research is to assess the potential of biofiltration to be established in African and Caribbean countries (AF\&CA) since there is no publication in this matter in the mentioned regions. To make possible this analysis, the approach consisted on an exhaust literature review about the state of the art of biofiltration and then, about the existence of regulations and possible emitting sources in these regions. It was also considered the availability of the biofilter materials and possible air pollution control services. Besides, a survey was done in order to assess the awareness of inhabitants about the use of technologies to control air pollutants.

\section{Biofilters for waste gas control}

Biofiltration is a technique that employs a biofilm, containing a consortium of microorganisms in contact with water and the air pollutants; which by consuming the organic compounds present in the waste gases sustain their growth and simultaneously eliminate the content of several pollutants in the exhaust gases. It has been proven as a very efficient technique for the treatment of VOCs and odor emissions [7]. The utilization of microorganisms for the degradation of odorous compounds was first registered in 1923, when Bach in 1923 [32] employed this approach for the treatment of hydrogen sulfide $\left(\mathrm{H}_{2} \mathrm{~S}\right)$ emissions from a sewage treatment plant, by using soil beds as filter material. During 1960 - 1970, intensive research was carried out in the USA, the Netherlands and in Germany in order to improve the removal efficiency of the biofilters. Some structural media were introduced, like bark, wood chips, polystyrene balls and others, 
mainly to minimize the medium compaction and the avoid flow resistance [2].

Among the main factors that influence biofiltration can be mentioned [2]: microorganisms, moisture content, temperature, oxygen content, $\mathrm{pH}$ and the biofilter medium. Fig. 1 exemplifies the principal components of a biofiltration system.

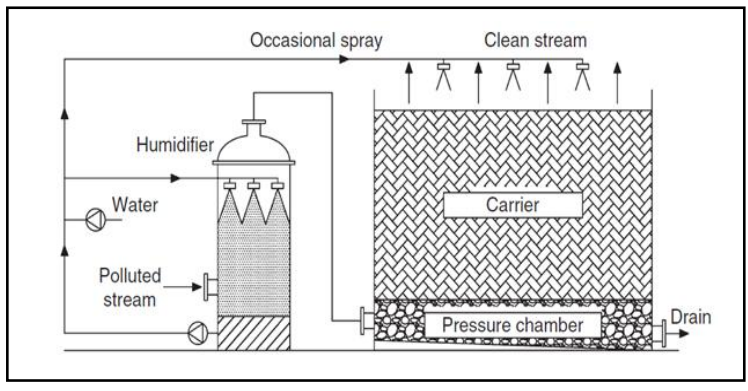

Figure 1. Scheme of a typical biofiltration system [31]

In order to keep an efficient functioning of biofilters, microorganisms play an important role, since they degrade the compounds in the off-gases. The good adaptation and performance of the microbial population is a function of the physical and chemical parameters in the bed. It is known that different groups of microorganisms are involved in biofiltration of air pollutants, for example: bacteria, yeast, fungi and protozoa [31].

Despite most of the void space is filled with air, the moisture in the biofilm is required to keep the microorganisms active. When the proportion of moisture is too low, the filter bed dehydrates and as a result, some orifices and short circuiting may develop; this leads to shrinkage in the biodegradation quota [31].

For biofiltration temperatures in the range of 15$40 \mathrm{oC}$ are recommended. It is important then to consider the temperature of the incoming gas stream and decide either a pre-cooling or heating of it. The appropriate content of oxygen in the bed depends on the microbial population; for example, aerobic heterotrophic bacteria need as minimum $5-15 \%$ oxygen in the input gas [31].

The $\mathrm{pH}$ in biofiltration is a function of: 1. type of biofilter media, 2 . microbial metabolism, 3. incoming gas composition, among other aspects. Synthetic materials normally have a neutral $\mathrm{pH}$, while natural materials are mainly acidic. This is due to the biological decomposition of the organic matter [31].

The following are relevant parameters to select an appropriate biofilter medium [30; 31].

- Sufficient surface area,

- Homogeneous structure, in order to evade elevated pressure drops,
- Mechanical support: availability of pores (void space) to supply good aeration drainage, oxygenation and correct passage of the inlet air stream, therefore reducing pressure drop,

- Sufficient nutrient composition, among others.

The contaminants passing through the biofilter supply the biofilm of carbon and from the air they take hydrogen and oxygen. The rest of nutrients, such like N, P, K, S, Ca, Fe and micronutrients, like vitamins and metals are provided depending on the type of biofilter material and its assembly [31].

Care should be taken to avoid the compression of the biofilter bed. Basically, when the height and the weight of the bed are too high, compaction may occur and the pass of air is significantly reduced, increasing the pressure drop. Normally, the filter bed volume is in the range $10-3000 \mathrm{~m} 3$, with a height between $0.5-2.5 \mathrm{~m}$ [31].

Optimal performance occurs when the gas is in contact with the biofilm for a period in a range of 1030 seconds, however, it varies according to the compound to be treated, for example, and some trichloroethylene may need even 150 minutes to be removed [30].

\section{Application of biofilters in Africa and Caribbean countries}

\section{A. African Countries}

\section{a) South Africa}

The government is configured in three independent domains which work interconnected to execute and supply directives that embrace air pollution control. The governmental sector is divided as national, provincial and municipal spheres [8]. The National Department of Environmental Affairs and Tourism (DEAT) is the controlling agent for environmental quality management. It supplies policies, standards and regulations to assure air quality in the country. Each one of its functions is described in the Air Quality Act. In terms of offensive odors, it is responsible to designate measures for their control [9].

The National Environmental Management: Air Quality Act (2004/2005), represents a new and advanced phase in respect to atmospheric pollution prevention. In this act, international best practices were considered, and more executive power is given to the local government in order to oversight and to manage the air quality and the compliance with the law [8]. 
In the governmental notice no. 248, Gazette no. 33064 of the South African Department of Environmental Affairs: "National Environmental Management: Air Quality Act (39/2004): List of activities which result in atmospheric emissions which have or may have a significant detrimental effect on the environment, including health, social conditions, economic conditions, ecological conditions or cultural heritage"[10] is compiled the national emission limit standards from South Africa in respect to VOCs, odors and chemical compounds of interest for biofiltration. It contains limit values for more than 8 industrial categories and subcategories.

\section{- Case NATREF}

Greeff [11] analyzed the VOCs emission control system of the National Refiners of South Africa (NATREF) in order to determine the efficiency of the plant. It was found that there were inappropriate VOCs emissions audit which causes a loss of three million rand per year, equivalent to $231,682.86$ $€ /$ year, due to VOCs discharges.

The sources of VOC emissions at refineries are located into three principal zones, which should be constantly monitored to avoid leakages: fugitive VOC emissions ( $40-60 \%$ of total VOC emissions), VOC emissions from the wastewater treatment zone $(10-15 \%)$, and, VOC emissions from storage tanks and product loading area ("tank farm"), representing $30-45 \%$ of total VOC emissions [11].

Regarding the availability of biofilter materials in South Africa, it was found that the following companies provide them: Blue Fig Landscaping, Hydro-Patch, Biz Afrika 1159 (Pty) Ltd, PurLec Hydroculture, The coir institute, Cactus Carbon (Pty) Ltd, Chemical Specialities Limited (ChemSpec), Organic Seeds, among others, including the Municipalities of Cape Town, Johannesburg, Breede River Winelands, Makana, Sol Plaatje. Some of the companies that provide services in air pollution control include: Cactus Carbon (Pty) Ltd, SGS South Africa (PTY) Ltd., Ilithia Group / Emissions Abatement Solutions / Scion Technologies: representative of: MEGTEC Systems Environmental Products, WSP Africa: Protherm, Zululand Filters (Pty) Ltd, BBR Enviro Systems, Sg Plastic, among others.

\section{b) Nigeria}

Nigeria implements a very extensive environmental administration. The main governmental institutions aimed at protecting the environment, creating policies and their implementations are: the Federal Ministry Environment, Housing and Urban Development and the National Environmental Standards and Regulations Enforcement Agency (NESREA) [12].

The National Guidelines and Standards for Industrial Effluents, Gaseous Emissions and Hazardous Waste Management in Nigeria (1988 No. 58) (publication of 1991) [13], stipulated by decree in 1988 at the time, by the Federal Environmental Protection Agency; contains all the emission limits standards in regards of waste waters and gaseous emissions from different sources. Under the section: "National Effluent Limitations and Gaseous Emissions Guidelines in Nigeria for Specific Industries" are listed the different activities and emission limits.

In this standard, there are 10 industrial sectors regulated. In some sectors there is no regulations in terms of emitted substances, however, the law recognizes there is a problem with them. This is the case of odors, for example in the following sectors: agricultural chemicals (odors from meat packaging, fish processing, coffee roasting, starch manufacturing and rendering some solid wastes); plastics and synthetics (Volatile organics hydrocarbons); tannery (particulate odor in boiler emissions, odor from plant processes). The waste waters from tanneries and textile mills were considered as odor emitters, but there are no limit values.

\section{- Case of Ibadan Oyo State}

Ibadan is the capital city of Oyo state in Nigeria. It is positioned in the geographical coordinates 354 $\mathrm{E}$ and $723 \mathrm{~N}$. This is the second largest and most urban city in southwestern Nigeria. Obayelu [14] did an investigation about the economical and environmental impact of odor emissions from mechanically ventilated livestock building in this state, by employing surveys to people working with poultry, pig and goat/sheep farms. People explained that the odors from livestock produce the following effects on them: headaches, nauseas, reflex nausea, gastrointestinal distress, fatigue, eye and throat irritation, shortness of breath, runny nose, sleep disturbance, inability to concentrate and typical stress reaction [14]. The same author offers a list of more than 14 options to reduce and avoid the generation of odors in farms, including the employment of biofilters.

The following companies provide biofilter materials in Nigeria: Aduayagada Investments Limited, Crystal Produce \& Projects Merchants L.T.D, Global Sterling Products Limited, Bulwark associates Nigeria Ltd., among others. Regarding the companies that provide services for air quality control, the following are listed: SGS Inspection Services Nigeria Ltd., MEGTEC Systems 
Environmental Products and WSP Group SA (Pty) Ltd.

\section{c) Ghana}

The Minister of Environment, Science and Technology is the governing institution in matters of environmental issues. It operates by the enforcement of the Environmental Protection Agency (EPA). After its formulation were conferred functions of compliance, enforcement and control in environmental aspects [15]. The Environmental Protection Agency Act of 1994, act 490 presents all the legislative functions of the EPA in terms of environmental enforcement, compliance and control, as a way to reach the National Environmental Policy in Ghana [16].

\section{- Case of Sunyani Abattoir}

Inhabitants of the community Nana Bosoma Central Market, in the nearby of the Suyani abattoir, have presented several complaints to the environmental agency in Ghana and even to the press, the Ghana News Agency (GNA). They complain about the bad smells originated from this place, due to the bad management and lack of hygiene [17].

This abattoir was installed in 1972 and since then, no reconstruction has been made. Local environmental responsible, Mr. Simon Opoku, Sunyani Municipal Environmental Officer agrees on the deplorable situation going on there, however, still no real changes have been made [17].

Regarding the availability of biofilter materials; the following companies were identified, which provide several of the biofilter materials: Accra Compost Plant, Deco! Sustainable farming, IBIC Ghana Limited, Tri-West Ghana Ltd, Purity Gold Ghana Limited, Timber solution 1td, African Center for Enterprise Development (ACED), among others. A company that provides services in VOCs and odors monitoring is: SGS Ghana Limited.

\section{d) Kenya}

The Ministry of Environment, Water and Natural resources is the directive institution in matters of environmental quality and pollution prevention. Some of its functions are: elaboration of policies directed at protecting the environment, to lead a sustainable management of natural resources, to promote the research and spread information regarding land resources and geology, to control and organize environmental activities and prosecute the compliance of environmental regulations and guidelines [18].
The Environmental Management and Coordination Act, 1999, is the mandate for the establishment of the National Environment Management Authority (NEMA). This represents the action section of the mentioned Ministry of Environment, Water and Natural resources [19].

In this act there is no information regarding the emission limits, however it indicates the creation of local organizations as enforcement institutions and receiver of issues regarding pollution and environmental problems. These institutions are [19]: the Provincial and District Environment Committee, and the Public Complaints Committee

- Planning of a Mini Leather industry in Isinya Town

In 2012, the Kenya Leather Development Council executed an environmental impact assessment with the coordination of the company Umwelt consults, in order to determine the potential impacts of the establishment of a mini leather industry in the Isinya town and district; under the specification of the Environmental Management and Coordination Act (EMCA) of 1999 [20].

The council had a budget of Kenya Shillings Ten Million (KES. 10, 000,000.00), equivalent to circa $90,000 €$, for the construction of the tannery. Moreover, a local organization, the Maasai Rural Training Institute (MRTI) supplied 2 acres of land for the location of the mentioned tannery [20].

As part of the environmental impact assessment, the generation of odors from the tannery was considered. However, the suggested control method was mainly by the application of chemical compounds. For the case of $\mathrm{H} 2 \mathrm{~S}$, the following substances were cited: bleach, sodium hypochlorite, calcium hypochlorite and ferric chloride. After the identification of possible air pollutants from the tannery process, some air pollution control techniques were listed, however, biofiltration was not considered among the BAT [20].

Some of the companies that provide biofilter materials are: CPZ, Ltd., Olarro, Kocos Kenya Ltd., TakaTaka Solutions Ltd., Live-Ex Resources, Envirosan International Ltd. Among the companies that provide air pollution control services in Kenya are: SGS Kenya Limited, MEGTEC Systems Environmental Products, among others.

\section{B. Caribbean Countries}

\section{a) Dominican Republic}

The Ministry of Environment and Natural Resources is the governmental institution responsible of the protection and conservation of the natural resources in the Dominican Republic. This is also 
responsible of the prosecution and penalization of any inappropriate action that acts against the sustainable management of resources and the established laws.

In the Dominican Rep., the regulating policy in the field of environmental protection is the General Law of Environment and Natural Resources, no. 6400, stipulated on August 18th, 2000. This law describes the functions of the mentioned Ministry, and incorporates aspects of sustainable management of natural resources, situations of crime against the environment and a more effective way of controlling pollution and protecting the environment. This law regulates in general VOCs, $\mathrm{H} 2 \mathrm{~S}$ and $\mathrm{PAH}$ from existing and new plants [21].

- Case of emissions inventory in the DR

In 2009, the Central American Commission of Environment and Development in conjunction with the Ministry of Environment and Natural Resources, developed a emissions inventory of seven selected air pollutants, including VOCs, generated from stationary sources, area sources and motor vehicles. The methodology employed was based on: direct measurements from sources, emission models (all of them elaborated by the US-EPA, such as: TANKS 3.1, LANDFILL, among others), interviews, emission factors (the source was the Air Chief Version 8) and material balances [22].

In the inventory, the annual VOCs emissions per source in the Dom. Rep. are: 119,794.6 ton/year VOCs and 30,836.5 ton/year NH3 from area sources; 437,730.9 ton/year VOCs and 882.9 ton/year NH3 from stationary sources. From all air pollutants emitted from the Dom. Rep., VOCs represent $32 \%$. The main emissions of VOCs correspond to the industrial sectors of food products, beverages, elaboration of oils, fats and tobacco [22].

Some of the companies that provide the biofilter materials in the Dominican Rep. are: Agroesa - Agro Espinar S.A., Exportadora de Productos Ecológicos C $x$ A, Asociación Dominicana de Agricultura Orgánica (ADAO), Laboratorios Sugar, Ferreteria Hache, Agroforestal Línea Fronteriza, Ebanistería del Norte, C.xA. (EBANOR), among others. However, no information regarding companies providing services for air pollution control/ biofiltration was found.

\section{b) Jamaica}

The governmental authority in charge of protecting the environment in Jamaica is the Ministry of Water, Land, Environment and Climate Change (MWLECC). The administrative and operating institution is the National Environment and Planning Agency (NEPA). This was mandated since April, 2001. The main goal is to provide effective solutions to environmental problems, and to elaborate sustainable policies in the field [23].

The following are the departments forming NEPA which execute its responsibilities [23]: applications management division, Policy, planning, evaluation \& research division, corporate management division, legal \& enforcement division and, integrated planning \& environment division.

The Natural Resources Conservation Authority Act [24] is the mandate document for the establishment of the regulating environmental agency in Jamaica. It also indicates national standard limit values, according to different industrial sources. In terms of stack emissions standards; this law prescribes emission limit values and regulations for the most relevant industrial facilities, such as: mineral industries, fuel combustion, petroleum refining, waste management and inorganic chemicals. No information regarding odor emissions was found, however, the only sectors with limitations for VOC emissions were: waste treatment and petroleum refining [24].

The Jamaican regulations for air pollutants have been based on the American and Canadian air quality regulations. Some governmental institutions with responsibility with the environmental air quality have assumed a list of toxic pollutants, which include relevant VOCs substances, and indicated standard limit values. These are mainly applicable to new facilities or when significant changes are made to existing facilities. These limit values are compiles under the same law and as "Ambient air quality guidelines for priority air pollutants (PAPAAQG)" [24].

- Negril \& Ocho Rios Wastewater Treatment Plants

The European Union has supported the construction and rehabilitation in 1998 and 2002, respectively of these two WWTPs in the tourist coastal towns of Negril and Ocho Rios. The investment accounted for more than 3,030,000.00€ via the 7 th European Development Fund (EDF) (7 ACP JM 23/24), promoting the economic growth of this region [25].

In 2005, an assessment was undertaken in this installation in order to determine the status and efficiency of the plants. Several deficiencies were found and recommendations were made. Some of the installations to be installed by 2010 were: a hydraulic surge protection, a sludge thickener, and an odor filter. The operating agency is the National Water Commission [25].

Information regarding services for VOCs or odors control was not found, however, there are companies that provide the materials for biofilters. Among them: Info Tech Limited, Pimento Coal 
Jamaica ltd., Evergrow Garden Center, Canco Limited - Ecowells Limited, among others.

\section{c) Trinidad and Tobago}

In Trinidad and Tobago, the principal institution related with environmental protection is the Ministry of the Environment and Water Resources (MEWR). The operating control agency is the Environmental Management Authority (EMA) [26]. The principal air pollution control policy is the Environmental Management Act, promulgated in 2000. In this act, EMA and its administrative structure is designed, joined with its functions. This act constitutes a legal framework for the protection of the environment and its management. In the chapter 35-05 of the Environmental Management Act are described the air pollution rules, the governmental authorities, fees that need to be paid in case of infractions and the national emission standards [27]. In this regulation, more than 10 VOCs are regulated.

\section{- Case of air quality in TT}

In order to determine the air quality status in Trinidad and Tobago, in 1999 an air quality assessment and modeling was conducted by the Town and Country Planning Division (TCPD) on representation of the Government of the Republic of Trinidad and Tobago (GORTT). Results indicated that the main anthropogenic sources of VOCs in this country are from manufacturing, including petroleum refining $25 \%$ and ammonia $41 \%$; followed by the sector transportation $21 \%$. While, the principal sources of ammonia emissions come from its manufacture. In this study, it was also appointed non-point sources of air pollution complaints, in which odors was included. These complaints originate from communities, and individuals, due to malodors from sewage treatment plants, dumps, landfills and burning of these [28].

Similarly, in Trinidad and Tobago, information regarding air pollution control/biofiltration services were not found. Nevertheless, the biofilter materials are available. Some of its distributors are: Plant Doctors Trinidad, Rodulfo Lumber Supplies, Meat Plus Ltd., Tracmac Engineering Ltd., among others.

\section{d) Cuba}

The Ministry of Science, Technology and Environment (CITMA) is the governmental coordinating institution responsible of executing and prosecuting the state norms in terms of sciences, technology and environment and for the use of nuclear energy, thus, there is a sustainable integration among these sectors [29].
It was not found information regarding national air quality standards that regulate odor or VOCs emissions. However, it was found regulations for typical green hause gases [33]. In the following website can be found all pertaining laws, policies, guidelines and governmental statements in Cuba:http://www.medioambiente.cu/legislacionambi ental/leyes.htm

\section{- Case of sugar cane industry}

This is a very important economical sector in Cuba. Annually, 10 to 20 million tons of bagasse are produced. Moreover, this industry releases large quantities of air pollutants as well as VOCs to the atmosphere, like ethanol, which is accounted to be 600 tons released per year in Cuba. In order to reutilize the byproduct generation of bagasse and determine the potential efficiency of this material as biofilter bed, a group of researchers developed an experiment for this context [30].

For this experiment, the type of biofilm was selected particularly to remove ethanol; the yeast specie Candida utilis was employed to propagate on the bagasse used as filter bed. The bagasse showed the advantages of being porous and compacted; some mineral salts were incorporated, such as ammonium nitrate to help the efficiency of the yeast [30].

Results indicated that this yeast can assimilate up to $250 \mathrm{~g}$ ethanol / (m3h) in optimal conditions. When bigger doses want to be incorporated, it should be done moderately, the same with the nutrient supply. Otherwise, there will be an overload of substances and the elimination efficiency will decrease significantly. Finally, it was suggested to continue the research at an industrial scale, since a successful result can benefit greatly this sector [30].

Biofilter materials are available in the following companies: Empresa Azucarera "Dos Ríos", Maprinter, ALCARBON S.A., RX bricolatges sl, among others. Information regarding services for biofiltration was not found.

\section{Results of the survey}

In order to gather information regarding the impression of inhabitants about the status of air quality regulations and potential of establishing biofiltration in their regions, an online survey was developed. The survey was running for 1 month, and was designed with the Google documents for spread sheets application. It comprised a list of 20 questions regarding: governmental institutions, laws, description of odor problems, knowledge about biofilters, techniques used to control odors, availability/prices of biofilter materials, among others. 
It was considered 61 African countries and 28 Caribbean Counties. The link of the survey was posted in online regional groups and also distributed by direct requests. In total, 92 responses were received. $70 \%$ of the participants came from the Caribbean region, while, $30 \%$ of the participants represented the African region. Fig. 2 indicates the main sources of odors in African and Caribbean countries, according to the participants of the survey.

People from Nigeria and Jamaica indicated that know the legal institutions regulating air quality, however, since it was an online survey, it could be possible that some people searched in internet. The other aspect is that even those who said yes, not necessarily indicated the correct institutions.

In the case of the Caribbean region, it is greatly marked that there is less awareness about the laws that protect the air quality. It is interesting to mark that all participants from Puerto Rico indicated that they know about the air quality laws.

In the African region, the main sources of odors indicated by the panelists were from waste waters, industry, and biological solid waste and in some extent agriculture. In the Caribbean, the picture was similar, having as the main sources emitting odors: waste waters, industry, biological solid waste and breweries. In both areas, the sector of landfills was not so prominent. Maybe the participants do not live in the nearby of constructed landfills or open dumps, as in many countries exist. In the Dominican Rep., participants indicated a significant affirmative response about claims due to odor annoyances.

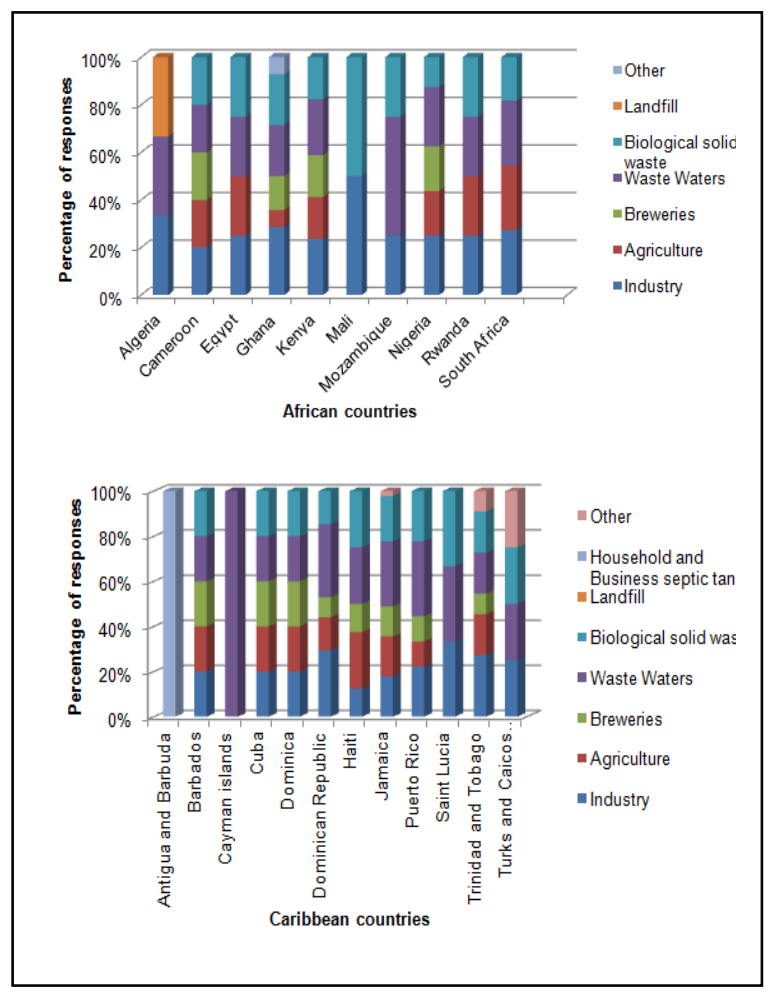

Figure 2. Main sources of odors in AF\&CA
As expected, most of the participants have never built or worked with biofilters, therefore, there is no experience with the technology among the participants of this survey from the AF\&CA. However, it is important to observe that in South Africa and in Ghana there are few people who have either built in the case of the first or worked with biofilters in the case of the second. In the Caribbean, there are people from Puerto Rico, Jamaica and the Dominican Rep. have built and worked with biofilters.

\section{Conclusions}

From the four African assessed countries, South Africa and Nigeria represent the most feasible countries for a prompt establishment of biofiltration as a convenient technology for the treatment of waste gases. In these countries are present modern air quality regulations and practical national emission standards that control VOCs from almost all industrial sectors.

Nevertheless, no clear policies regarding odor emissions control still exist. In all of the evaluated African countries exist consulting companies that provide services for the measurement and monitoring of VOCs and odors. In the Dom. Rep., Jamaica and Trinidad and Tobago, emission targets and limits for some VOCs in certain industrial cases were found, however, in the case of Cuba, this information was very restricted.

In the Caribbean countries, most of the typical biofilter materials were also found at affordable prices, some could be found even almost for free. From the survey, people recognize that there are problems with odors, especially emitted from waste waters, industry and biological solid waste, nonetheless, few information regarding control techniques was offered. Biofiltration was practically unknown by the participants. Most of the people corroborated the existence of biofilter bed material in their countries.

The results of this research indicate that this technology has great applicability in these regions and its introduction will benefit enormously, towards the protection of the air quality, while fostering improvement to human health.

\section{Acknowledgements}

Extensive thanks to the sponsors: International Postgraduate Studies in Water Technologies scholarship (IPSWAT) and the Institute for Sanitary Engineering, Water Quality and Solid Waste Management (ISWA). 


\section{References}

[1] K. Hansmann, and C. Kroeger. Environmental management policies: A comparison of reactive and proactive approaches. Greener Manufacturing and Operations: From Design to Delivery and Back, 2001, pp. 191-204 (14).

[2] J.S. Devinny, M.A. Deshusses, and T.S. Webster. Biofiltration for air pollution control, CRC Press, LLC, Boca Raton, FL (1999).

[3] Atkinson, R. and Arey, J. (2003). Atmospheric degradation of volatile organic compounds. Journal of Chem. Rev. Vol. 103, pp. 4605-4638.

[4] A. Nanda, P. Sarangi, and J. Abraham. Microbial biofiltration technology for odour abatement: an introductory review. Journal of Soil Science and Environmental Management, Vo. 3 (2), 2012, pp. 28-35. [5] J. Nicell. Assessment and regulation of odour impacts. Journal of Atmospheric Environment 43, 2009, pp. 196-206.

[6] D. Luo, R. Corey, R. Propper, J. Collins, A. Komorniczak, M. Davis, N. Berger, and S. Lum. Comprehensive environmental impact assessment of exempt volatile organic compounds in California. Journal of Environmental Science and Policy. Vol 14, 2011, pp. 585-593.

[7] S. Adler. Biofiltration: a primer. American Institute for Chemical Engineers: Center for Waste Reduction Technologies (CEP). Magazine Environmental Protection, 2001, pp. 33-41.

[8] Y. Naiker, R.D. Diab, M. Zunckel, E.T. Hayes. Introduction of local air quality management in South Africa: overview and challenges. Journal of Environmental Science and Policy. Vol 17, pp. 62 - 71, 2012.

[9] South African Ministry of environmental affairs and tourism. National framework: for air quality management in the Republic of South Africa. (Online). Access date: 07.07. 2013. Available here:

http://www.saaqis.org.za/Downloads.aspx?type=AQ

[10] National Environmental Management: Air Quality Act (39/2004): List of activities which result in atmospheric emissions which have or may have a significant detrimental effect on the environment, including health, social conditions, economic conditions, ecological conditions or cultural heritage" from march 2010, act no. 39, part of the Air Quality Act from 2004.

[11] M. Greeff. Evaluation of the monitoring system for volatile organic compound (VOC) emissions at NATREF, South Africa. Mini-dissertation submitted in partial fulfilment of the requirements for the degree Magister Environmental Management in Geography and Environmental Studies at the North West University, Potchefstroom campus, 2004.

[12] M. T. Ladan. Law, Cases and Policies on Energy, Mineral Resources, Climate Change, Environment, Water,
Maritime and Human Rights in Nigeria. The Ahmadu Bello University Press, Zaria, 2009.

[13] National Guidelines and Standards for Industrial Effluents, Gaseous Emissions and Hazardous Waste Management in Nigeria (1988 No. 58). Federal Government of Nigeria and the Federal Environmental Protection Agency, 1991.

[14] A. Obayelu. Assessment of the economic and environmental effects of odor emission from mechanically ventilated livestock building in Ibadan Oyo State Nigeria. International Journal of Science and Nature, Vol. 1 (2), pp. $113-119,2010$.

[15] W. Ahorttor, and G. Asiamah. Compliance and enforcement in Ghana. Fifth International Conference on Environmental Compliance and Enforcement, 1998. (Online). Access date: 13.07.2013. Available here: http://www.inece.org/5thvol1/ahorttor.pdf

[16] Environmental Protection Agency Act. Act 490, 1994. (Online). Access date: 13.07.2013. Available here: http://www.lexadin.nl/wlg/legis/nofr/oeur/lxwegha.htm

[17] ghanabusinessnews.com. Contagious disease outbreak feared around Sunyani abattoir. (Online). Access date: 17.07.13. Available here:

www.ghanabusinessnews.com/2013/04/30/contagiousdisease-outbreak-feared-around-sunyaniabattoir/\#sthash.cUcDC0BU.dpuf

[18] Ministry of Environment, Water and Natural resources (Online). Access date: 13.07.2013. Available here:

http://www.environment.go.ke/about

[19] Environmental Management and Coordination Act., 1999, Act. No 8. (Online). Access date: 13.07.2013. Available here:

http://asareca.org/PAAP/Policy\%20Instruments/Kenya\%2 0Environmental\%20Management\%20Act\%201999.pdf

[20] Umwelt consults. EIA study report for the proposed construction of a mini-leather processing unit at Masai rural training centre in Isinya, Kajiado county, 2012. (Online). Access date: 05.08.13. Available here: http://www.nema.go.ke/index.php?option=com_phocadow nload\&view=category\&download=439:eia923-studyreport-isinya-mini-leather-processing-unit-dec2pdf\&id=114:eia920-929-reports

[21] Normas ambientales de calidad del aire y control de emisiones. Ley 64-2000 sobre medio ambiente y recursos naturales. Secretaría de estado de medio ambiente y recursos naturales subsecretaría de gestión ambiental. (Online). Access date:: 14.07.13. Available here: http://www.procuraduria.gov.do/PGR.NET/Dependencias/ Ambiente/Nosotros/Calidad\%20del\%20Aire.pdf

[22] J. Herrera. Inventario de Emisiones de Contaminantes Criterio de República Dominicana. Comisión Centroamericana de Ambiente y Desarrollo (CCAD), 619 p., 2009. 
[23] National Environment \& Planning Agency. (Online). Access date: 14.07.13. Available here: http://www.nepa.gov.jm/about/tour/index.asp

[24] Natural Resources Conservation Authority Act 2006. Ambient air quality: guideline document. National Environment and Planning Authority. Jamaica. (Online). Access date: 14.07.13. Available here:

http://www.nepa.gov.jm/regulations/air-ambient-guideline2006.pdf

[25] European External Action Service. Jamaica Rehabilitation Negril \& Ocho Rios Wastewater Treatment Plants. (On-line). Access date: 14.07.13. Available here: http://eeas.europa.eu/delegations/jamaica/projects/list_of_p rojects/18966_en.htm

[26] D. Schim. Review of national policies, plans \& reports. National Capacity Self Assessment (NCSA). Magazine the trust for sustainable livelihood, technical bulletin no. 1, 2004.

[27] Environmental Management Act. Air pollution rules and fees. Republic of Trinidad and Tobago. (Online). Access date: 14.07.13. Available here:

http://www.ema.co.tt/docs/legal/airfeereg.pdf

[28] Delegation of the European Commission and the National Authorizing Officer of the European Development Fund. Trinidad and Tobago: joint annual report 2004. Trinidad and Tobago - European community cooperation. (Online). Access date: 14.07.13. Available here:

http://ec.europa.eu/development/icenter/repository/TT_fina 1_2005_en.pdf

[29] Ministry of Science, Technology and Environment (CITMA). (Online). Access date: 14.07.13. Available here: http://www.medioambiente.cu/organigrama.asp\#top

[30] E. Bolcu. Agricultural waste products as filter media and as cover materials in biofilters for Mediterranean countries. PhD Thesis, Institut für Siedlungswasserbau, Wassergüte und Adballwirtschaft der Universität Stuttgart, 2006.

[31] G. Cabrera, M Martinez, and D. Cantero. Biofilters. Journal of Engineering Fundamentals of Biotechnology, Vol. 2, 2011, pp. 303-318.

[32] G. Leson and A. Winer. Biofiltration: an innovative air pollution control technology for VOC emissions. Journal of the Air \& Waste Management Association, 41:8, 1991, pp. 1045-1054.

[33]Y. Muñoz. La contaminación atmosférica y la contaminación por factores que afectan la salud humana. su relación con las inmisiones. Universidad Central "Marta Abreu" de las Villas. Unión Nacional de Juristas de Cuba (UNJC), 2005. 